\title{
Leveling Differences and Reinforcing Similarities: The Interaction between Information and Communication Technologies and National Culture
}

\author{
Jan-Oddvar Sørnes \\ Bodø Graduate School of Business \\ Bodø, Norway \\ Jan.Oddvar.Soernes@hibo.no \\ Alf Steinar Sætre \\ Norwegian University of Science and \\ Technology, Trondheim, Norway
}

\author{
Keri K. Stephens \\ The University of Texas at Austin \\ Austin, TX, USA \\ keriste@mail.utexas.edu
Larry Davis Browning
The University of Texas at Austin
Austin, TX, USA

Ibrowning@mail.utexas.edu

alfs@iot.ntnu.no

\section{Abstract}

This study compares how workers in Norway and the United States use Information and Communication Technologies (ICTs). Our data-72 in-depth interviews of advanced ICT users - was coded and analyzed using a grounded-theory methodology. As our organizing structure of comparing the two countries, we use Hofstede's four-dimensional framework of national culture. Our results show that ICTs have a homogenizing effect on cultural differences - but also a reinforcing effect on existing similarities. We hypothesize possible explanations for these findings, including tracing them to our focus on an expert-user subculture and external triggering events.

Keywords : Culture, Information and Communication Technologies, Cross-cultural studies, Organizational Communication

\section{Introduction}

Modern technology is radically changing how much of the world now communicates, collects, stores, uses, and distributes information. That transformation is being driven by Information and Communication Technologies (ICTs), which allow entirely new ways of working in both the physical and the virtual world (Avolio, Kahai \& Dodge, 2001). Not surprisingly, much of the public discussion has focused on technical issues, especially the workings of the Internet and World Wide Web (WWW). The increasingly global nature of organizational relationships, fueled by the worldwide reach of these technologies, enables exchanges across national borders (Drucker, 1993), even blurring those same borders. Yet while the technology itself is mesmerizing, these emerging ICTs are being used by people in social contexts,

Material published as part of these proceedings, either on-line or in print, is copyrighted by Informing Science. Permission to make digital or paper copy of part or all of these works for personal or classroom use is granted without fee provided that the copies are not made or distributed for profit or commercial advantage AND that copies 1) bear this notice in full and 2) give the full citation on the first page. It is permissible to abstract these works so long as credit is given. To copy in all other cases or to republish or to post on a server or to redistribute to lists requires specific permission from the publisher at Publisher@InformingScience.org so it is critical to explore exactly how individuals, groups, and national cultures are affecting-and being affected by-ICTs.

Our own focus here is specifically on how ICT use affects culture. Though we acknowledge evidence suggesting how national culture might affect ICT use, our raw data consists of individual reports of ICT use. We essentially use national 
culture as a sorting variable that allows us to compare, with greater discrimination, ICT use between the Norwegians and Americans. We rely on Hofstede's four-dimensional cultural framework (1980) as a baseline to see if current ICT use in organizations reflects national-culture differences. We use Hofstede's framework to organize our analysis, because it's considered the reigning study of crosscultural differences and because it has spawned hundreds of follow-up studies. The analysis reported here is part of a broader investigation of ICT use in the workplace in Norway and the United States.

In the following sections we review literature on ICT use and practices in the workplace, focusing especially on studies that compare ICT practices across national borders. Since the relationship between ICT use and culture is recursive and intertwined, we review literature on how national culture and ICT use affect each other. Then, we summarize Hofstede's four-dimensional framework and show how it applies to ICT use. Next, we offer four hypotheses based on predicted existing cultural differences between Norway and the United States. Then we describe our methodological approach and present our findings, using narrative examples from the interviews. Finally, we discuss the implications of those findings in relation to Hofstede's cultural dimensions, and explain our findings using Orlikowski's (2000) 'practice lens" perspective.

\section{ICTs and National Culture}

The last three decades have produced a growing body of research studying organizations' use of ICTs (see Hollingshead \& Contractor, 2002, for a review). By "ICTs" we mean all technologies that facilitate the handling of information and enable different forms of communication among human actors, between human beings and electronic systems, and among electronic systems (Hamelink, 1999). Research has focused on: media choice-how people make choices about the different media they use in their communication with others (e.g., Daft \& Lengel, 1984; Trevino et al., 1990; El-Shinnawy \& Markus, 1997); media effects-how technologies can impact group interaction processes and group outcomes (e.g., Hilz \& Turoff, 1978; Sproull \& Kiesler, 1991; McGrath \& Hollingshead, 1993); and the interaction between ICTs and group/individual interaction (e.g., Poole \& Desanctis, 1990; Orlikowski \& Robey, 1991; Zack \& Mckenney, 1995). Because the literature on ICT use and its sister terms in organizations is substantial (for reviews, see Fulk \& Boyd, 1991; Garton \& Wellman, 1995; Flanagin \& Metzger, 2001; Dewett \& Jones, 2000; Straub \& Karahanna, 1998; Poole, 2000; Lievrouw \& Livingstone, 2002; Hollingshead \& Contractor, 2002), we will restrict our review to those studies that inform our understanding of the relationship between ICTs and national culture.

The relationship between technology and culture is complex, and many studies have explored it. Some, for example, have explored cultural influences on technology development and innovation (Herbig, 1994), cultural influences on technology adoption (Straub, 1994), and culture as a factor in the diffusion of the Internet (Maitland, 1999; Cronin, 1996; Goodman, Press, Ruth, and Rutkowski, 1994). A few studies have also examined how technology affects culture. This happens to be our own primary focus. Here, research has focused on how new ICTs change social structures (Latane \& Bourgeous, 1996) and on norms of communication (Dutton, Rogers \& Jun, 1987; Caron, Giroux \& Deuzou, 1989).

But there are few studies that actually compare ICT use between nations, and most of that research examines only a single ICT. These studies are summarized in Table 1:

Table 1. Summary of Comparative Studies of ICT and Culture

\begin{tabular}{|l|l|}
\hline El Shinnaway \& Vinze (1997) & $\begin{array}{l}\text { Examined the impact of technology and culture in the process and } \\
\text { outcomes of group decision-making in the U.S. and Singapore. }\end{array}$ \\
\hline Rice, D’Ambra, \& More (1998) & $\begin{array}{l}\text { Tested managers from } 4 \text { countries and their perceptions of media } \\
\text { equivocality of } 4 \text { different media in work-related situations. }\end{array}$ \\
\hline
\end{tabular}


Sørnes, Stephens, Sætre, \& Browning

\begin{tabular}{|c|c|}
\hline Png et al. (2001) & $\begin{array}{l}\text { Based on data from a multinational survey, this study demonstrates } \\
\text { the relationship between national culture and corporate adoption of IT } \\
\text { infrastructure. }\end{array}$ \\
\hline Tan et al. (1998) & $\begin{array}{l}\text { Tested the impact of ICTs on majority influence in individualistic } \\
\text { (U.S.) and collectivistic (Singapore) culture. }\end{array}$ \\
\hline $\begin{array}{l}\text { Ulijn, Lincke \& Karakaya } \\
\text { (2001) }\end{array}$ & $\begin{array}{l}\text { Studied } 20 \text { individuals from Europe (Nordic and Latin) and from } \\
\text { North America (Anglo) and the effects of culture on non-face-to-face } \\
\text { communication. }\end{array}$ \\
\hline Straub (1994) & $\begin{array}{l}\text { Studied the effect of culture on IT diffusion of email and Fax in Japan } \\
\text { and the U.S. }\end{array}$ \\
\hline Straub, Keil \& Brenner (1997) & $\begin{array}{l}\text { Compared the technology acceptance model (TAM) across } 3 \text { different } \\
\text { countries: Japan, Switzerland, and the U.S.. }\end{array}$ \\
\hline Veiga, Floyd \& Dechant (2001) & $\begin{array}{l}\text { Discussed the effects of national culture on IT implementation and } \\
\text { acceptance. }\end{array}$ \\
\hline $\begin{array}{l}\text { Leidner, Carlsson \& Corrales } \\
\text { (1999) }\end{array}$ & $\begin{array}{l}\text { Tested managers using Executive Information Systems (EIS) across } \\
\text { many organizations in Mexico, Sweden, and the U.S., for cultural } \\
\text { differences. }\end{array}$ \\
\hline Calhoun, Teng \& Cheon (2002) & $\begin{array}{l}\text { Tested the impact of national culture on information-technology us- } \\
\text { age behavior related to decision-making in the U.S. and Korea. }\end{array}$ \\
\hline Van Birgelen et al. (2002) & $\begin{array}{l}\text { Compared ICT use in after-sales service-and-support operations in } \\
\text { Sweden, Belgium, France, Spain, Austria, Ireland, Netherlands, } \\
\text { United Kingdom, Norway, and the U.S. }\end{array}$ \\
\hline Hofstede (2000) & $\begin{array}{l}\text { Empirically studied the influences in technology adoption in } 56 \text { coun- } \\
\text { tries, using GNP figures from the World Bank. }\end{array}$ \\
\hline Mejias et al. (1996/97) & $\begin{array}{l}\text { Did a cross-cultural comparison of GSS and non GSS outcomes } \\
\text { within and between the U.S. and Mexico. }\end{array}$ \\
\hline Gattiger \& Nelligan (1988) & $\begin{array}{l}\text { Studied the range of adoption and implementation decisions of ICTs } \\
\text { in the workplace between the U.S. and Canada }\end{array}$ \\
\hline
\end{tabular}

It is rare to find studies looking at multiple ICTs in combination, and those that exist have thus far used only college students as their survey respondents (e.g., Flanigin \& Metzger, 2001; Savolainen, 1999). Therefore, this study of multiple ICTs across national cultures is unique. Not only does it extend the cultural comparison literature listed above, but it also capitalizes on the need to study many ICTs in context. Sitkin et al. (1992) claim that much of the ICT literature facilely assumes that users employ a single ICT for a given task. They argue - rightly, we believe - that studies of multiple channels and communicators offer a solid place for future researchers to tread.

\section{Cultural Frameworks}

Culture has always proved a thorny construct, and the ways to describe and compare national cultures range from stereotypes to empirically derived models. Though treating culture as an explanatory factor when comparing countries is hardly uncommon, it is recognized that cross-cultural contributions in this area "remain in a state of infancy" because of disagreements over how to define "culture" and because of the methodological and resource difficulties inherent in such studies (Straub et al., 2002, p.18). As anthropologists would agree, culture is unquantifiable, so that puts enormous responsibility on the researcher to construct a plausible operational definition (Maitland, 1999). Slack and Wise (2002) argue that cultural studies are especially suited for revealing and critiquing the often positive bias found in 
Leveling Differences and Reinforcing Similarities

studies of new technology. In the following paragraphs, we lay out different approaches for undertaking cultural comparisons.

Half a century ago, Kroeber and Kluckhohn (1952) identified more than 160 definitions of culture. Since then, the number of definitions has mushroomed to approximately 400 (Ferraro, 1994). It's not necessary to address this huge inventory of definitions here, so we will cite the most respected frameworks for examining cultural differences at the national level (see Stohl, 2001 and Merchant, 2002 for reviews). These include: Kluckhohn and Strodtbeck's (1961) framework of six dimensions; Trompenaars' seven dimensions of culture (Trompenaars, 1993); Edward T. Hall's (1976) high- and low-context societies; Gannon and associates' (1994) metaphor perspective; Gudykunst and Ting-Toomey's (1988) four styles of verbal communication; and Hofstede's (1980) four dimensions of cultural values. Most of the frameworks focus on averages or norms of the cultures' systems rather than on precise descriptions (Stohl, 2001; Merchant, 2002). The studies attempt to represent approximate expected beha vior by individuals in a specific culture, while conceding that everyone in that culture does not act alike. Indeed, variations within single cultures are often greater than across cultures (Hofstede, 1991). Collectively, these frameworks contribute to a better understanding of why individuals from different cultures behave diversely. But it is hard to justify one being better, or more correct, than another.

In the present study we adopt Hofstede's (1980, p. 21) notion of culture as "the collective programming of the mind which distinguishes the members in one human group from another." In cross-national research, people from different cultural and ethnic backgrounds are referred to as having "different mindsets," where "mindsets" refers to all those concepts related to cultural similarities and differences (Hofstede, 1991). One assertion by Hofstede that's important to our study is that culture "is learned," not only "inherited." This supports the belief theory that individuals can both learn and unlearn cultural traits based on environmental influences such as ICTs.

After more than 20 years of use, Hofstede's dimensions of national culture are often used by academics, consultants, and management groups to help sort out, and understand, differences between national cultures. Based on a massive survey of more that 50 countries, involving more than 120,000 respondents, Hofstede (1980) presented a model of national culture that posited four dimensions, or rating mechanisms: Power Distance Index (PDI), Uncertainty Avoidance Index (UAI), Individualism/Collectivism (IDV), and Masculinity/Femininity (MAS). More recently, a fifth dimension, Long vs. Short-Term Orientation, was added. We don't include this dimension here because it was introduced only to account for a missing "eastern" perspective in the original four dimensions. Those original dimensions had been faulted for portraying only a "western" way of thinking (Hofstede, 1991). While Hofstede's system is certainly not perfect, several studies confirm the validity of its dimensions (e.g., Ronen \& Schenkar, 1995; Straub, 1994; Fernandez et al. (1997); Sondergaard, 1994) and use them to account for empirical observations (e.g., Earley 1993, Straub, 1994. See also Sondergaard, 1990, and Hofstede, 2001, for a review of follow-up studies, and Smith, 2002 for an in-depth analysis and critique.

Hofstede (1980) asserts that central tendencies in a nation will be replicated in their institutions through the behavior of individuals. Following Smith's advice (2002), we think it is appropriate to use individual accounts as the unit of analysis when samples are drawn from two, or just a few, nations. As Tayeb (2001) argues, "The main advantage of breaking down culture into its constituents characteristics is that it facilitates comparison across cultures; one looks at the same trait and observes similarities or differences among the nations under investigation or even notes its absence from some culture altogether" ( $p$. 93). Similarly, Hofstede (1991) argues that his framework "can serve to explain and understand observed similarities and differences between matched phenomena in different countries" (p. 14).

By choosing Hofstede, we follow the advice of Smith (2002), who argues that cross-cultural comparisons have value only if they're related to a formulated theory. The present study uses Hofstede's (1980) model for three reasons. First, it has been shown to be stable and useful for numerous studies across 
many disciplines. Second, his research and arguments are compelling to organizational researchers, because even before empirical testing, links can be seen between his four dimensions and many aspects of international organizational behavior (Sackman, 1997). Included are familiar constructs such as decision-making, political risk (UAI), leadership, authority relations (PDI), importance of work goals, interpersonal relations (MAS), and motivation and compensation systems (IDV). And third, Hofstede's framework explicitly links national cultural values to communication practices; communication practices using ICTs are central to our study (Samovar, 1981; Stohl, 2001; Merchant, 2002). Furthermore, Hofstede's work and conceptualization of culture have been used by many researchers in their attempt to explain the role of ICTs in the workplace (e.g., Dafoulas \& Macaulay, 2001; Vogel, Davison, Shroff \& Qureshi, 2001; Straub et al., 2002; Rathod \& Miranda 1999; Cagiltay, 1999).

\section{Norway vs. the U.S.}

The most common strategy found in cross-cultural research is to compare groups from very different perspectives (e.g., Japan vs. the U.S.) because it increases cultural specificity. We have chosen here to compare two rather similar cultures, each possessing universal education, social welfare systems, and institutions dominated by Judeo-Christian thinking (Aukrust \& Snow, 1998). Furthermore, we have chosen samples that are similar on several key variables that are often concerns in studies such as ours. Both Norway and the U.S. have similar penetration of ICTs, and both have many expert users, too. In a way, we control for these variables by comparing similar countries.

The diffusion of advanced ICTs is among the highest in the world in Norway and the United States. Since the late 1980s, Norway and other Nordic countries have engaged in an ambitious program for telecommunications reform. While previously lagging behind the U.S., they have managed to narrow this historical gap considerably (Bauer, Berne \& Maitland, 2002). Norway issued its "National Action Plan for IT" in 1987, making it one of the first countries in Europe to do so, and shortly thereafter many other European countries followed suit, as did the U.S. with its "Agenda for Action" (1993). Actual use of the Internet is far higher in Norway (and the other Nordic countries) than in any other European country, and is at approximately the same level as in the U.S. More than half the population in these countries uses the Internet on a daily basis, which is likely to have some impact on communication patterns and lifestyles (Lundby, 2002). Another study found similarities between the U.S. and the Nordic countries when comparing structural, regulatory, and competitive variables in the telecommunications sector (Bauer, Berne, and Maitland, 2002). According to Henten and Kristenson (2000), these two countries can be seen as societies that are similar in having advanced information societies. These similarities serve to lessen the often confounding effects of differential digital-divide issues and user-experience levels.

\section{Hofstede's Four Dimensions of Cultural Differences}

Despite the similarities, Hofstede's model shows that at a more micro level there are differences between Norway and the U.S. These differences and similarities provide the impetus for our study. Table 2 compares the two countries: 
Table 2. Norwegian and U.S. scores on Hofstede's 4 Dimensions

\begin{tabular}{|l|l|l|l|l|l|}
\hline Country & PDI & UAI & IDV & MAS & Total \\
\hline U.S. & 40 & 46 & 91 & 62 & 157 \\
\hline Norway & 31 & 50 & 69 & 8 & 158 \\
\hline $\begin{array}{l}\text { Range (IBM } \\
\text { Study) }\end{array}$ & $11-104$ & $8-112$ & $6-91$ & $5-95$ & \\
\hline
\end{tabular}

To best understand how Hofstede's framework might be affected by ICTs, we provide a detailed description of each dimension, from which we build to our research hypotheses. On the first two dimensions, Norway and the U.S. are quite similar; but on the final two dimensions, they are different.

\section{Power Distance (PDI)}

Hofstede's first dimension (1991), the Power Distance Index (PDI), reveals dependence relationships in a country, or more precisely, the extent to which less powerful members of a society accept unequal power distribution. Small power-distance countries, such as Norway (extremely low) and the United States (moderately low), show limited acceptance of power inequality and less dependence of subordinates on bosses. They also show a preference for consultation and cooperation, that is, interdependence between boss and subordinates. In low PDI cultures, subordinates and superiors consider each other as essentially equal; "the hierarchical system is just an inequality of roles" that is established for convenience (Hofstede, 1991, p. 36). We should therefore expect to find examples of close working relationships between boss and subordinate, but also examples of assertive behavior by subordinates, such as their defining their own work tasks.

Furthermore, attitudes toward ICT use will be enhanced by a decision and implementation process that increases users' sense of participation in the choice of new ICTs (Flo yd and Dechants, 2001). We should therefore expect to find evidence of resistance in situations where new ICTs, and policy pertaining to their use, is implemented without the participation of members below top management.

Relating the low PDI more directly to ICT use, we predict high usage of rich media such as face-to-face, since there are few communication barriers based on status or power issues. This encourages frank, informal contact between boss/subordinate (Jarvenpaa, Rao and Huber, 1988). Furthermore, low PDI cultures are also likely to use "lean media" in a number of situations just for efficiency. Along the same lines, contrary to high PDI cultures, where emphasis is put on showing one's identity and thereby revealing one's status, in low PDF cultures people are more likely to mute their identity since it has lesser bearing in the communication process and the outcome (Ho et al., 1989).

Considering that Norway and the U.S. differ by only 9 points on Hofstede's 93-point scale, we predict many similarities and thus propose the following hypothesis:

Hypothesis 1: By examining ICT use in Norway and the United States, we expect to find similarity on the Power Distance dimension.

\section{Uncertainty Avoidance Index (UAI)}

The second dimension in Hofstede's (1991) original conceptualization is labeled the "Uncertainty Avoidance Index" (UAI), which Hofstede defines as the "extent to which the members of a culture feel threatened by uncertain or unknown situations" (Hofstede, 1991, p. 113). Hofstede originally discovered this dimension as a byproduct of the Power Distance Index (PDI), so there are certain similarities and 
overlaps between these two dimensions. He borrowed the term from American organizational sociology - in particular, from the work of James G. March Norway and the United States are labeled "moderately low" in this dimension, indicating their ability to accommodate ambiguity and uncertainty in the workplace.

In cultures with low UAI, there is less need for predictability and written and unwritten rules to guide work tasks. Due to less rule-dependency, these cultures are more trusting than their counterparts Mooij, 2000). This may lead to early experimentation with, and adoption of, new ICTs, and the use of multiple technologies in their working tasks (Floyd and Dechants, 2001; Maitland \& Bauer, 2001). Also, employers will seldom try to impose company rules on ICT usage, and if they do, it's likely that people will challenge or break such rules for pragmatic reasons (Floyd \& Dechants, 2001). Furthermore, these countries are normally heavy users of ICTs, especially "lean" media, both in the workplace and at home. Both the freedom and the lack of structure on the Internet make it a good fit for low UAI cultures, and we would therefore expect to find examples of heavy use of multiple ICTs (Mooij, 2000).

Hofstede asserts that the level of uncertainty and ambiguity found in a culture profoundly affects how institutions are organized and managed (Hofstede, 1983). Consistent with this logic, low UAI will therefore likely affect how individuals choose media for their communication tasks (Straub, 1994). For ICT usage we should therefore expect to see individuals using multiple channels for somewhat similar tasks as well as different ICTs in combination. In situations of high ambiguity and uncertainty, on the other hand, we would therefore expect to find great variation in what ICTs are chosen, due to a lack of strict patterns and individual differences. As early adopters of ICT, both cultures should display evidence of innovative and advanced usage patterns (Maitland \& Bauer, 2001). Yet another aspect of this dimension deals with the age differences of users. In cultures with low scores, older people, often higher up in the company hierarchy, are more apt to leave tasks and great responsibility in the hands of younger workers (Hofstede, 1980). This is congruent with Hofstede's listing of specific characteristics of low UAI cultures, where he found that managers often depend on expert opinions from workers lower down in the hierarchy. In contrast with high UAI cultures, managers don't need to be experts in the field they manage (Hofstede, 1991).

Since both Norway and the U.S., are within 4 points (out of a 104-point scale) of each other, we expect them to behave almost identically with respect to this dimension. This leads to the following hypothesis:

Hypothesis 2: By examining ICT use in Norway and the United States, we expect to find considerable similarity on the Uncertainty Avoidance dimension.

\section{Individualism/Collectivism (IDV)}

Hofstede's (1991) last two dimensions use a scale metaphor, and for this particular dimension countries are either labeled "individualistic" or "collectivistic." While recognizing that most societies have some characteristics of both, we base our definition on Hofstede's original conceptualization. "Individualism" pertains to societies where individual ties are loose and everyone is expected to look out for themselves and their family. In "collectivist" societies, on the other hand, people are integrated at birth into strongly cohesive in-groups, and group loyalty lasts a lifetime. In the organizational context, individualism or collectivism emphasized in a particular culture has a direct bearing on behavior. In Hofstede's study, the United States scores highest of all nations on this dimension, while Norway scored moderately high.

The notion that "time is money" is prevalent in individualistic countries, causing individuals to manage their time tightly (Trompenaars \& Hampden-Turner, 1998). Another time-related feature is their ability to schedule and handle several tasks either simultaneously or sequentially. As Floyd and Deschants (2001) found, "in individualistic cultures new IT will be more likely viewed as useful when it is perceived as enhancing the performance of the individual." 
Since such cultures emphasize personal accomplishments and productivity, the time and effort required to establish or maintain a personal relationship are often compromised in order to get the job done. In short, in individualistic societies, the task will normally prevail over any personal relationship. Relevant ICT use and communication efforts are displayed by searching and querying new information sources like company Webpages or through the participation in Newsgroups. In an individualistic culture, people therefore seem to be more innovative and trusting in exchange relationships with external parties (Van Birgelen et al., 2002).

Despite both countries being categorized as individualist, there is a 20-point spread (on the 85- point scale) between them. This suggests that there are likely to be some differences, and it leads to the following hypothesis:

Hypothesis 3: When its ICT use is examined, Norway will appear slightly more collective than the highly individualist U.S.

\section{Masculinity/Femininity Index (MAS)}

Although Norway and the United States score similarly on the three previous dimensions, they show a stark contrast on the last one - the Masculinity/Femininity Index (MAS). In broad terms, "masculinity" pertains to societies where social gender roles are clearly distinct (i.e., "masculine" countries value assertiveness and focus on material success, while "feminine" countries value modesty, tenderness, and quality of life (Hofstede, 1991). Given the value placed on modesty in more "feminine" cultures, Triandis (1995) asserts that individuals from such cultures don't like to stick out - that is, be unique or conspic uous - unlike the more assertive and career-seeking individuals found in countries like the United States. The "live in order to work vs. work in order to live" dichotomy is often used to illustrate the fundamental difference, but we believe further distinction is in order. The United States scores moderately high in this dimension and is thus labeled "masculine," while Norway scores extremely low and is thus very "feminine."

Mooij found that feminine cultures don't restrict their need for quality of life to the privacy of their home alone, but extend it into the workplace as well. Leisure and personal activities, such as reading news and watching television, may be tolerable at work (Mooij, 2000). This is not so in masculine cultures, where a stricter task orientation prevails. We should therefore expect to see differences between the U.S. and Norway with regard to distinctions made between work and leisure activities in the workplace. Even if feminine cultures are likely to draw clear boundaries between the workplace and the private sphere, workers in those cultures are prone to take work home just to be with their families. Hofstede's (2000) findings support this assertion and claim that one-way devices (e.g., Fax) will be more prominent in masculine countries, while two-way devices (e.g., cell phones) are more likely to be adopted in feminine countries, as they enable contact even after regular working hours.

The prediction of these differences leads to the following hypothesis:

Hypothesis 4: Based on Hofstede's findings on Masculinity/Femininity (MAS), where the United States scores moderately high and Norway scores extremely low, we expect to find greater dissimilarity than similarity in ICT use.

\section{Method}

As previously noted, this study builds on a grounded-theory analysis of ICT use (Stephens, Browning, Soernes, Schmisseur, \& Saetre, 2002). While the original research was an empirical theory-building piece, the categorized data serves as a solid foundation for this cultural analysis. The methodology is also appropriate for our current cultural work because the topic is emergent and difficult to quantifiably measure (Patton, 1990). Straus and Corbin (1990) explain that qualitative research is useful for giving 
"intricate details of phenomena that are difficult to convey with quantitative methods" (p. 19). Since we rely on the original categorization, we will first provide some details pertaining to the original study. Then we will describe the analyses conducted for the current research.

\section{Participants}

Following the advice of Straub and his associates, we used the individual as the unit of analysis, even though culture is usually considered a group-level phenomenon (Straub et al., 2002). Culture can only manifest itself through individuals in a society, as there is no way to query or probe into the collective unconscious of an entire culture. Once the individual-level data is collected, "it will also be possible to assert that certain cultural characteristics do or do not belong to certain cultures" (Straub et al., 2002, p. 19).

Our sample consisted of people in various levels of management who worked for organizations based in the U.S. and Norway. The industries represented were diverse in size and type. They included: elearning, farming, fish-farming, higher education/R\&D, medicine, the law, software-production, telecommunications, semiconductors, oil and gas, and government agencies. We used a judgment sampling method whereby individual respondents were chosen based on their experiences, ability to reflect, and ability to articulate the information solicited (Morse, 1991). They consisted of a cross-section of users from different functional areas, ethnicities, professional and organizational tenure, and gender. Finally, we considered the nature of their work tasks and proactively sought experienced ICT users. The purpose for gathering data from such a wide and diverse sample was to ensure maximum variations of behaviors in different situations (Lincoln \& Guba 1985).

\section{Data Collection}

The data for the original study was collected over a two-year period, from the fall of 2000 through the fall of 2002. During this time, four researchers conducted 72 individual interviews -36 in the U.S. and 36 in Norway. Each interview lasted 45-90 minutes and was audio-recorded. To collect the data, we used semi-structured, in-depth interviews. Because this research involved many sites and multiple interviewers, and because we wanted to maintain cross-case comparability (Miles \& Huberman, 1994), we felt it especially important to use a similar format for all our interviews. To ensure this consistency, we created an interview guide based on Spradley's (1979) "grand tour type" design. This approach focuses on relaxing participants during the data-collection process, and it also invites detailed responses from them. The interview guide began with questions focused on how participants used ICTs in their daily work. From this point, questions moved on to a more interactive level by querying interviewees about their ICT use when working with others. The recordings of these interviews, once transcribed, resulted in over 2,000 pages of text. The entire Norwegian data set was translated into English by each of the two Norwegian interviewers, working separately. Then they carefully verified each other's translations to ensure contextual and semantic accuracy.

\section{Data Analysis}

The original study used a grounded-theory methodology (Glaser, 2002; Charmaz, 2000; Glaser \& Strauss, 1967; Strauss \& Corbin, 1990) for the reasons mentioned previously and also because it lets researchers modify their analyses as further data is gathered (Charmaz, 2000).

Our process consisted of two main steps: (1) incident identification, and (2) categorization. First, we marked individual units of data-called "incidents"- ranging from single sentences to short paragraphs. Three of four researchers (the fourth conducted the interview, thus they did not analyze it) labeled the incidents; these were then combined, and duplicates were removed. The process resulted in 4,972 indi- 
vidual incidents. All of these incidents were then sorted into a category system using Glaser's (1978) constant comparative analysis process. Once again, three of the four researchers participated in this focused coding (Glaser, 1978). Since the three categorizers didn't always agree, a final categorization was undertaken. In this process, two of the four researchers independently categorized the entire data set. Then, by working together to resolve any disagreements, they achieved a doubly categorized data set that resulted in 59 unique categories. These final 59 are the categories that organize the raw data used in the current study.

\section{Current Cultural Data Analysis}

Our study takes advantage of the existing database on ICT use and the fact that each raw code was attributed to either a Norwegian or an American. As we organized our data in an Excel spreadsheet, we were able to sort our data for this purpose. Based on the conceptualization of Hofstede's four dimensions, all four researchers independently recoded the data, in the existing 59-category system, into one or more of Hofstede's four dimensions. When a category was placed in more than one dimension, we examined the raw data. Using raw-data frequency counts and clear definitions of Hofstede's framework, we identified the categories that loaded most strongly on a given Hofstede dimension. A final joint coding session was conducted between all researchers wherein minor disagreements were resolved.

To illustrate how the data informs Hofstede's framework, we selected narratives from the interviews. We used the researchers' intimacy with the data, as well as searches of our data base, to select the narratives used for analysis in this paper. This is consistent with Glaser's (1978) view that researchers may flexibly draw on and construct frameworks based on the theoretical leads suggested by their data. Similarly, Strauss (1970) admits that while the emphasis in the 1967 monograph with Barney Glaser was theory generation, its analytical style could also be used in the context of previously developed theoryas long as it had been carefully grounded in research. In our findings, presented in the following sections, we describe what we learn about national culture from the narrative analysis of ICT use.

\section{Findings}

In this study we use the individual reports of ICT use from both Norwegians and Americans to test the validity of Hofstede's four cultural dimensions. Overall we find support for our first two hypotheses Power Distance (PDI) and Uncertainty Avoidance (UAI). But we also find that the second two hypotheses-Individualism (IDV) and Masculinity (MAS ) — are disconfirmed. To demonstrate these findings, we provide details of the data categories that loaded heavily into each dimension. We then focus on presenting narrative accounts for selected categories that demonstrate our conclusions.

\section{Power Distance (PDI)}

Based on Hofstede's PDI, where both Norway and the United States score low, we expect to find considerable similarity in ICT use. During data analysis, the following categories from our dataset were found to inform this dimension (Table 3):

Table 3: Categories for PDI

\begin{tabular}{|l|l|}
\hline Category Name & Description of Category \\
\hline Use of Paper & $\begin{array}{l}\text { Shows that paper still has its place as a medium, especially in formal and } \\
\text { important communications. }\end{array}$ \\
\hline Newsgroups & $\begin{array}{l}\text { Discusses the use of Newsgroups for problem-solving and information- } \\
\text { gathering — both personal and professional use. }\end{array}$ \\
\hline
\end{tabular}


Sørnes, Stephens, Sætre, \& Browning

\begin{tabular}{|l|l|}
\hline $\begin{array}{l}\text { Generation Gap of } \\
\text { Users }\end{array}$ & $\begin{array}{l}\text { Discusses how age affects attitude towards ICT use, and how older people } \\
\text { in particular are generally more skeptical and old-fashioned in dealing with } \\
\text { technology. }\end{array}$ \\
\hline Hierarchy & $\begin{array}{l}\text { Discusses how internal information must often be translated between differ- } \\
\text { ent organizational levels. }\end{array}$ \\
\hline Anonymity & Discusses how Web and email users can protect their anonymity. \\
\hline
\end{tabular}

Our findings for this dimension indicate high concurrence with Hofstede's general description of low (Norway) and moderately low (U.S.) PDI. Hofstede conceptualizes equality between superiors and subordinates as a trait of low PDI, and we found numerous accounts of close working relationships between these organizational groups. The examples are taken from the Hierarchy category. The following comment, an example from the Norwegian dataset, illustrates how this mutually dependent relationship between boss and subordinates is solved in a competitive intelligence team: "We have intentionally placed ourselves in a star formation around a circular table at work where we have our computers and a little personal workspace... The whole idea is to have visual contact and the conversation flowing, as this is valued by everybody in the group." This example consists of a four-person group, where one of them is the manager. This respondent further explains: "The ability to interact and communicate throughout the day is essential to what we do ... team members depend on each other for reliable information." We see here a mutual dependency between boss and subordinates in their effort to produce timely competitive intelligence on their opponents. A US interviewee echoes this mutual dependency by explaining how the organization, "requires everyone else to follow the same PC organization scheme." The reason for this is so that everyone, including managers can cover for each other when they are out of the office.

Another attribute of low PDI is that work tasks and ICT preferences may be initiated by the subordinates themselves and not just by their bosses. A Norwegian interviewee demonstrates that there is a mix between the two: "The tasks may be self- selected or assigned by top-management-usually a 40/60 split in that order." A US manager explains that she prefers to use email for everything, but she also recognizes that for her employees that work with customers, they need to operate in a face-to-face environment. She explains this by saying, “The office needs diversity. It's boring if everyone uses ICTs the same way." While independence is valued in both cultures, giving employees too much freedom during work hours can backfire. In the following example, an employer recalls finding out that one of his employees spent too much time on the Internet chatting (ICQ) during work hours: "I told her to cut it out, so to speak ... she didn't talk to me for a few days, but she stopped doing it." Even in low PDI cultures, direct commands occasionally shape behavior.

Just because attempts at leveling the status differential are made, examples from the Hierarchy category demonstrate that power differences still exist. The following two examples from both countries show how the interviewees are less concerned with quality when communicating with subordinates than they are when communicating with superiors or colleagues of equal rank. A Norwegian professor said: "When I communicate with students I have a certain authority, right? ... I can sit and write anything and hit Return immediately. But when I communicate with colleagues, then I am more thoughtful on what I am actually writing." A U.S. consultant, meanwhile, said the following about correcting spelling errors when using email: "If it's to anybody who is more senior than me, I will always fix it."

Members of low PDI cultures feel strongly about making their own decisions concerning ICT use. Likewise, when decisions about ICT implementation are discussed at the organizational level, they like to be involved. The following example from the Norwegian dataset demonstrates this preference: "The College has purchased a system that forces you to use a particular logic, and the decision to buy the system was made independent of what we as faculty think of such a system." Similarly, a U.S. respondent finds her company's restrictive policy on voice mail to be very inflexible, and would like more latitude: 
"My current company is a very voice-mail kind of culture." She describes this informal policy as something that has essentially become a part of the corporate culture. Basically, our interviewees demonstrated their desire for inclusion by complaining about systems that had been adopted without their input.

Contrary to high PDI cultures that emphasize showing one's identity and status, the opposite is true for low PDI cultures like Norway and the United States. Two categories we combined to provide examples of this are Newsgroups and Anonymity. Here, power, gender, and race have little impact, and information [in Newsgroups] is shared freely. One Norwegian interviewee and frequent user of Newsgroups has wondered about what kind of people actually participate, and concludes that they are probably "enthus iasts, idealists, people who probably live in front of the screen - possibly students, university people, and those so-called nerds in the basement." He explains that Newsgroup participants do not even list their titles, and they are judged on the merits of their responses to posted questions. Even in this open environment, though, individuals vary in their preferences for anonymity. Some people prefer to disguise their identity, while others give the matter no weight. One interviewee from the U.S. said, "The younger generation uses nicknames to identify themselves, but older people use their real names." The younger individuals may want to conceal their identity for one of two reasons: (a) they don't want to expose their ignorance on a topic, or (b) they find that nicknames make digital communication more informal and accessible.

Overall, the findings on how ICTs are used in the U.S. and Norway support Hofstede's claim that both countries are moderately low with respect to Power Distance. The examples illustrate close working relationships between superiors and subordinates, yet also suggest some concern for power issues. There is evidence in both countries that they want to be involved in decisions about new technology adoptions. Finally, we see that status and identity issues are not a big concern and there is variation in how these are communicated.

\section{Uncertainty Avoidance (UAI)}

Based on Hofstede's findings on UAI, where both Norway and the United States score moderately low, we expect many similarities in ICT use. During data analysis, the following categories from our dataset were found to inform this dimension (Table 4):

Table 4: Categories for UAI

\begin{tabular}{|l|l|}
\hline Category Name & Description of Category \\
\hline $\begin{array}{l}\text { How the Web Affects } \\
\text { Organizational Process }\end{array}$ & $\begin{array}{l}\text { Shows how the Internet improves organizational work by speeding up } \\
\text { information searches, enhancing customer support, facilitating informa- } \\
\text { tion-sharing, and streamlining operations. }\end{array}$ \\
\hline $\begin{array}{l}\text { Selecting the Right ICT } \\
\text { for the Task }\end{array}$ & $\begin{array}{l}\text { Discusses how different media and channels are chosen to carry out a } \\
\text { task (e.g., contacts), including the most efficient way of communicating } \\
\text { with internal and external customers. }\end{array}$ \\
\hline Sequence of ICT Choice & $\begin{array}{l}\text { Deals with which channels (FtF, email, phone, voicemail, memo, Inter- } \\
\text { net, etc.) are used, and in what sequence, when communicating with } \\
\text { internal and external customers. }\end{array}$ \\
\hline Control & $\begin{array}{l}\text { Identifies how ICTs help control information and relationships by such } \\
\text { means as leaving a paper trail, emphasizing security, and being con- } \\
\text { sciously redundant. }\end{array}$ \\
\hline $\begin{array}{l}\text { Desire for Future Tech- } \\
\text { nology }\end{array}$ & $\begin{array}{l}\text { Discusses desires for new technology such as streaming processes and } \\
\text { personal productivity enhancements. }\end{array}$ \\
\hline
\end{tabular}


Sørnes, Stephens, Sætre, \& Browning

\begin{tabular}{|l|l|}
\hline Rules of ICT Use & $\begin{array}{l}\text { Includes instances of media or channel use based on company policy or } \\
\text { institutional expectations. Includes examples of both compliance and } \\
\text { noncompliance. }\end{array}$
\end{tabular}

ICT use can be considered a rudimentary activity for reducing uncertainty and ambiguity. Since this is a study of high-end users about how they use ICTs to search for and communicate information, it's not surprising that much of our data fell into this category. In fact, most of our 59 categories were found to inform this dimension to some extent. The final six categories listed above stood above the other 53 in their explanatory value for this dimension. Norway and the United States are both moderately low on UAI, and out of all four dimensions this is where one would expect the nations to be most similar.

ICTs such as the Internet are normally well diffused in low UAI cultures, as they represent personal freedom to choose various media without adhering to rigid rules and structures. Our data confirms this, as most of the interviewees used multiple channels for similar tasks and used different ICTs in combination. Two of our largest categories, Selecting the Right ICT for the Task and Sequence of ICT Choice, help explain UAI. A Norwegian respondent said that his usual approach to getting new customers was to (a) search for information on the Web, (b) email the companies identified, (c) phone them to get more personal contact, and (d) arrange a face-to-face meeting. In the same way, a U.S. interviewee made the following remark when talking about staying in touch with her communication partners: "a combination of everything [ICTs] is absolutely essential." These examples show how ICTs are used sequentially to reduce uncertainty.

Another of our categories, Rules of ICT Use, informs the UAI dimension as it accounts for both compliance and non-compliance with organizational policies on ICT use. Working off of Hofstede's conceptualization, we expected that members of low UAI cultures would be more likely to deviate from company policy. A Norwegian respondent talks about being part of a company policy "mutiny" by implementing his own solution: "There was a tremendous uproar, of course, but we were at the mercy of the functionality of this software. It had all these problems that we would not accept, so no one was motivated to start with it." Similarly, a U.S. respondent talks about "fooling" the online meeting-scheduling system. While company policy required full disclosure of available time slots for meetings on the online calendar, she was able to manipulate this: "If I need to be at home I'll just put myself out of the office." Another Norwegian respondent also broke company rules by downloading software off the Internet, saying, "We have a policy that individuals are not supposed to download and install such things, but we do it anyways. Sometimes when you need something right away, it is very tempting just to download it from the Internet." These examples demonstrate employees' willingness to break rules in an effort to customize or improve existing systems.

As hypothesized, low UAI cultures are expected to be innovative and display advanced use of ICTs. We would therefore expect to find evidence of early adoption of new ICTs, coupled with the desire for new ICTs. Our category labeled Desire for Future Technology includes examples of how new ICTs may enhance one's communication efforts. While talking about the limitations of using a laptop computer during meetings, a Norwegian said, "There is no doubt that an overgrown Palm [Pilot] would have been incredibly practical." Another Norwegian expressed the desire for a more efficient searching mechanism on the WWW: "I would like a search engine that gave about 20 highly useful links instead of 3,000 hits that just matched my search keyword. I would also like to see a system or tool that checked for quality." A U.S. respondent, who is in sales, would like to get information about people accessing their WWW pages: "A tool that would mine data from people visiting our Website would be helpful—a way to figure out who they are." The ability to figure out who visits Websites would clearly reduce the environmental uncertainty facing the organization and enable its employees to better tailor their sales approach. These examples illustrate the inclination in both countries to think innovatively and find better ways of reducing uncertainty through ICT use. 
The last set of findings concerning delegation is closely linked to descriptions of low PDI cultures as well as low UAI. Unlike cultures with high UAI, where managers are expected to be experts in the field they manage, our data shows that tasks are often delegated to subordinates. The following two examples are taken from the Control category and exhibit low UAI action. A U.S. respondent talks about how the task of updating a course Web page is delegated to teaching assistants: "While the professor is off doing research or teaching the class, they expect the assistants to use the technology-to put content up there and update the grade book." A Norwegian manager also turned to his subordinates when faced with a problem that required information searching, explaining, "I am more inclined to go ask somebody across the hallway than searching for information on the Internet [myself]."

It's not surprising that the U.S. and Norway are similar in the Uncertainty Avoidance dimension, because both countries have embraced new ICTs. In prior studies this dimension has been explored heavily as a predictor of likelihood of ICT adoption. These findings clearly show that when allowed access to many ICTs, low UAI countries will experiment with using them in sequence and even break existing rules to accomplish tasks.

\section{Individualism (IDV)}

Individualism is the dimension where the U.S. ranks highest in Hofstede's study. Even though Norway also scores relatively high here, we expected to find some differences. During data analysis, the following 6 categories from our dataset were found to inform this dimension (Table 5):

Table 5 : Categories for IDV

\begin{tabular}{|l|l|}
\hline Category Name & Description of Category \\
\hline Email Norms & $\begin{array}{l}\text { Describes how interviewees use email as their chief medium of } \\
\text { communication. Discusses issues such as appropriateness, email } \\
\text { use for information-sharing, and CYA (self-protective) tenden- } \\
\text { cies. }\end{array}$ \\
\hline $\begin{array}{l}\text { Efficiency/Time- } \\
\text { Savings }\end{array}$ & $\begin{array}{l}\text { Discusses how people use ICTs to increase efficiency and save } \\
\text { time. }\end{array}$ \\
\hline Creliability of Sources: & $\begin{array}{l}\text { Includes the need for credible information sources, the way } \\
\text { source credibility is assessed, and the expressed common charac- } \\
\text { teristics of credible sources. Also includes information on trust- } \\
\text { building and the importance of trust. }\end{array}$ \\
\hline Collaboration & $\begin{array}{l}\text { Includes formal and informal information-seeking and information- } \\
\text { sharing behaviors. }\end{array}$ \\
\hline Telephone Norms & $\begin{array}{l}\text { Discusses how people use the telephone to (a) work with custom- } \\
\text { ers, (b) share information, (c) take conference calls, and (d) } \\
\text { communicate. Also includes information on the telephone's ap- } \\
\text { propriateness and its relationship to other mediums, whether } \\
\text { richer or leaner. }\end{array}$ \\
\hline Just-In-Time Learning & $\begin{array}{l}\text { Discusses the importance of managing the learning process indi- } \\
\text { vidually, not through a formal corporate system. The intervie wees } \\
\text { discuss how learning is needed just-in-time rather than just-in- } \\
\text { case. }\end{array}$ \\
\hline
\end{tabular}

Our data did not support our hypothesis since both of these nations show characteristics of both individualism and collectivism. Actually, it was difficult to tell if comments in the interviewees came from a Norwegian or an American because the accounts sounded so similar. In individualistic cultures, ICTs are viewed as useful when they enhance the performance of the individual. This is especially observable in 
the categories Email Norms, Telephone Norms, and Time Savings/Efficiency, as respondents from both countries display high consciousness about using these ICTs efficiently. A very strong account of this was made by a U.S. respondent: "I manage a job that I wouldn't even have taken if email didn't exist." He went on to explain that technology helps him look good and accomplish much more in less time. A Norwegian interviewee found out that some of his communication partners did not answer emails in a timely fashion, so the telephone was more appropriate: "I almost never use email with those people anymore-I know there is no point. I can send one email after another and I don't get an answer anyway." These examples demonstrate how efficiency is determined by each individual's timeliness of responses.

The learning process - Just-in-time learning — can also be very efficient and fairly collectivistic when using ICTs such as the WWW. A Norwegian respondent makes this point well: "Colossal numbers of people around the whole world who have encountered the same issues have published solutions on the Net someplace or another. You skip having to invent gunpowder again." Correspondingly, a U.S. respondent states that the Internet is powerful because it holds "the wisdom of hundreds of millions of people." Yet another example by a Norwegian respondent emphasizes this point: "I just like the idea of posting a question [on Usenet] before you leave work, and the next day you can read some answers. It seems like there is always someone out there that is willing to lend a helping hand." Although these statements display high collectivism, we found that most of our respondents draw more from the Internet than they contribute themselves. In other words, individuals are focused on their own personal need for information. This seems to be a mix of individualistic and collectivist actions since true collectivism would dictate group loyalty and reciprocal contributions.

The category Just-In-Time Learning also shows that individualism is fostered by ICTs in that synchrony is not required for either individual action or learning to occur. Using the Internet as a tool for learning can take many forms, ranging from downloading tutorial documents to direct contact with individuals (strangers) through email or various discussion forums. A comment by a Norwegian respondent illustrates the individualist nature well: "I have not been to a course in 10 years, and everything I have learned I have taught myself, via the Net for the most part." Similarly, a U.S. respondent talks about the value of the Internet for staying abreast of the constant need for new knowledge in her job: "Using the Internet for research just makes me smarter." This focus on what "me" the individual gets from the Internet clearly demonstrates individualism.

As demonstrated, while the dominant characteristic seen here is individualism, both cultures also display collectivist values. Many of these comments, also found in Newsgroups category, concern the value of shared information. While the data don't support our hypothesis, the findings are interesting with respect to the similar comments made by the interviewees representing both cultures.

\section{Masculinity (MAS)}

Our final hypothesis predicted considerable differences between the United States and Norway with respect to the Masculinity dimension. This is based on Hofstede's findings where the United States scores moderately high, and Norway extremely low on MAS. The following 6 categories were found to inform this dimension (Table 6).

Table 6: Categories for MAS

\begin{tabular}{|l|l|}
\hline Category Name & Description of Category \\
\hline Competitive Intelligence & $\begin{array}{l}\text { Includes how people use ICTs to gather information about the market } \\
\text { and competitors. }\end{array}$ \\
\hline Work/Fun/Flow & $\begin{array}{l}\text { Discusses people's positive and negative perceptions about using tech- } \\
\text { nology for job enhancement, personal use, and play. }\end{array}$ \\
\hline
\end{tabular}


Leveling Differences and Reinforcing Similarities

\begin{tabular}{|l|l|}
\hline $\begin{array}{l}\text { Receiver Communication } \\
\text { Preference }\end{array}$ & $\begin{array}{l}\text { Deals with a customer's preferred communication channel, whether } \\
\text { actually expressed or only inferred. }\end{array}$ \\
\hline Cell Phone (SMS) & $\begin{array}{l}\text { Discusses the use of cellphones and SMS for professional and private } \\
\text { purposes. }\end{array}$ \\
\hline $\begin{array}{l}\text { September } 11^{\text {th }} \\
\text { Crash }\end{array}$ & $\begin{array}{l}\text { Discusses the impact of these two events on professional and personal } \\
\text { ICT use. }\end{array}$ \\
\hline
\end{tabular}

The "live in order to work (U.S.) - work in order to live (Norway)" dichotomy is ingrained in most of Hofstede's writings on MAS. Given this clear dichotomy we should therefore expect to find evidence of such differences in our data. We did not. In fact, we found the Norwegians to be very masculine (e.g., assertive, desirous of challenging work tasks, eager for individual recognition at work) and the Americans to be feminine at times.

One category that informs the MAS dimension is Competitive Intelligence. As expected, we found numerous accounts demonstrating assertive and pro-active information-seeking in the U.S. dataset. But, more surprisingly, we found similar behavior in the Norwegian dataset. One plausible explanation for this is extensive deregulation and privatization during the last decade, especially in the telecommunications sector. As one respondent put it, "It's all about competitive ability in a market that is becoming big and aggressive - even in Norway." Another Norwegian interviewee was in charge of setting up an office abroad, and he told us his strategy for recruiting personnel: "We were lucky and managed to recruit the trading manager from our largest competitor; he brought a mountain of networks and competencies with him." Furthermore, a Norwegian respondent used competitors' WWW pages in bidding rounds: "A lot of times a customer is negotiating with several bidders, and it's important for me to find out what the other guy has to offer. I can usually find the information I need by accessing their homepage."

We also found numerous accounts in the U.S. dataset of femininity - the desire by people to "work in order to live." This contradicts the notion that a strict task orientation prevails in masculine cultures. The following examples are taken from the category Work/Fun/Flow, and they demonstrate how U.S. respondents use company time for leisure activities. One U.S. respondent finds the introduction of Internet-related services into the workplace to be quite paradoxical: "Ironically, companies provide access to the Internet, and employees use it on company time to get a new job or retreat from work." Another U.S. respondent talks about the extensive use of virtual communities (e.g., Yahoo discussion groups) on the Internet for pursuing personal interests in politics, music, and arts: "We also use the Internet to actually download the compressed form of bootlegs... We burn it, spread it all over ... that's the kind of things we use the technology for-to communicate with people and transmit the music." While some of our respondents felt comfortable talking about their personal ICT use, often on company time, we realize that others would feel uncomfortable revealing such habits.

The following examples from the Norwegian dataset, also taken from the category Work/ Fun/ Flow, illustrate that there is no clear distinction between work and private sphere. One interviewee said: "My work is also my hobby, so I don't use my computer and Internet any different at home. It is hard to differentiate between what's work-related and what isn't." Another Norwegian example also illustrates this blurred boundary: "I have free time, of course, but some periods in the project are so hectic that I must prioritize it before other free- time activities." We found numerous accounts of this in the U.S. dataset as well. For example, one respondent said, "I extend the day to where I work usually an hour in the morning, an hour or two at night, and then probably about two, three hours on the weekend." Evidence of masculinity in the United States based on these criteria wasn't surprising; however, the Norwegian data also prominently displayed this as well.

The category Cell phone initially emerged from our data as interviewees in both countries talked about the value of individuals to be "available" by cell phones even after regular working hours. An example 
from the Norwegian dataset illustrates this: "The motivation for giving employees cellphones is that we have a clear policy that when the cell phone is on, we can call them anytime, day or night." While this example illustrates masculinity, we also found numerous accounts of cell phone use for social support, hence low masculinity. A U.S. respondent said the following when asked about the impact of the September $11^{\text {th }}$ terror attack of the World Trade Center: "The cell phone bus iness went in the 'pink' right after that; because I think people realized how much they want that ability to be in touch." Another U.S. interviewee finds great value in using cell phones to stay in touch with her kids while at work: "I think it is a security for the parents because they have that direct link to their child, and not only can they speak directly, but they can leave a message." Accounts of cell phone use for non-work- related communication are also found in the Norwegian dataset. The following example illustrates the consequences of giving employees free cell phones, which includes the possibility of sending SMSs (Short Message System):

It can be practical to send text messages to people, but we have employees who send 1,000 text messages a month on company cell phones. One thing is that it takes time to send 1,000 text messages, but it also costs a great deal of money.

Furthermore, we expected to find a higher display of cell phone usage in Norway due to a much higher penetration than in the U.S. This was not so, as the majority of respondents in the category were from the U.S. dataset. This is probably accounted for because we selected advanced ICT users for interviews from both countries.

As conceptualized by Hofstede, modesty and resistance to "sticking out" are characteristics of low masculinity; however, we found examples illustrating the opposite in the Norwegian dataset. A respondent working with a competitive intelligence team offered the following answer when asked how he managed to provide his boss with competitive information in a timely fashion: "I could probably put together a 30-page PowerPoint presentation—on anything — and have it completed by tomorrow." The example illustrates articulated high self-esteem, which is unusual in Norway, due to the national emphasis on modesty and toning down of one's own accomplishments.

Our categories labeled Dot.Com Crash and 9/11 emerged from our second-year dataset, based on direct questions on the impact of these two events. While Norwegian respondents for the most part answered that it had no impact on their business or work tasks, many also reported that they spent more time reading news on-line. Some interviewees also reported less travel, especially to the United States, and more use of ICTs such as videoconferences for meetings. Respondents with business relations or connections with the United States reported that they used ICTs to express moral support, especially after September $11^{\text {th }}$. Most of our respondents from the United States reported a substantial impact of these two events on their business practices_-more specifically, their ICT usage. One respondent reported less use of his computer: "The computer stopped being the main highway for communication, and more focus was put on restoring the social fabric." Another interviewee reported how on-line communities on the WWW changed after 9/11:

It was very interesting to me to be able to read and see and hear perspectives from people who I had never met and will never probably meet ... I have noticed that since then it has had the same effect on the Web that it had on the whole nation. We had for a while there a kinder, ge ntler Web.

Another respondent reported the following effect of the dot.com crash: "People were walking around with their cell phone, the pager - 'I'm so busy, I'm so busy, I'm so important, I'm so important ...' Now people have slowed down at least $20 \%$." 


\section{Discussion}

By using Hofstede's framework to examine how ICT use affects national culture, we found that cultural similarities were reinforced and differences were reduced or leveled. This means that our first two hypotheses were supported, but the last two weren't. While Hofstede called his dimensions characteristics of an entire national culture, we view our findings as more localized. It's important to remember that this was a workplace study of 72 individuals who are all high-end ICT users, so they were a specialized subset of the general population. Furthermore, even though we acknowledge and see evidence in the data of how national culture might affect ICT use, our data primarily enables us to investigate how ICTs affect national culture. We used Hofstede's concept of national culture as a sorting variable to compare ICT use between the Norwegians and Americans, and then relied on Hofstede's cultural framework as a baseline to see if current ICT use in organizations reflects nationalculture differences. Therefore, we prefer to interpret these findings from the stance of how they are capable of potentially changing the way national culture appears in local circumstances.

The findings for the first two hypotheses support the idea that ICT use in Norway and the U.S. reflects Hofstede's findings for Power Distance (PDI) and Uncertainty Avoidance (UAI). On both of these dimensions the two countries are quite similar. This suggests that ICTs do in fact reflect the status differential between superiors and subordinates. The finding also presents evidence that in cultures where ICTs are extensively disseminated, they are used in many different ways. The willingness to accept uncertainty (UAI) opens the door for new appropriations of individual ICTs and sequences of their use. These new appropriations can be explained using Orlikowski's (2000) perspective on technologies in practice. Her practice lens "focuses on emergent technology structures enacted in practice rather than embodied structures fixed in technologies" (p. 408). She uses a structuration approach to understand how repeated interaction with technology creates "sets of rules and resources that are (re)constituted in people's recurrent engagement with the technologies at hand" (p. 407). It is quite possible that in cultures with moderate to low UAI, as in this study, there is a willingness to experiment with ICTs rather than simply accept the features embedded in their original design. But since there is a recursive relationship between ICT use and culture, this also suggests that changes in either variable can affect the PDI and UAI dimensions in the future.

In hypotheses three and four, IDV and MAS, we predicted that there would be cultural differences between Norway and the U.S. in ICT use based on Hofstede's findings. But we found that ICT use looks almost the same on these dimensions regardless of national culture. We interpret this by explaining that the posited variation might be leveled through the use of ICTs. The data for both these dimensions clearly illustrates a lessening of the extremes, resulting in a change for both cultures.

As mentioned earlier, the U.S. scored the highest total of all Hofstede's studied cultures with respect to the individualism dimension. While our data still suggests that the U.S. is highly individualistic, we also see evidence of collectivist behavior, especially in how email and the telephone are used to facilitate personal relationships. On the other hand, Norway was expected to exhibit more collectivist tendencies than the U.S., yet on this dimension, the U.S. and Norwegian interviews look almost identical. Specifically, Norwegians are equally concerned with high productivity and task-strongly individualistic characteristics - and both countries use ICTs in similar ways. There is also a strong focus in both countries on using the Internet for just-in-time learning - that is, learning when a single person needs the information. This is highly individualistic and reflects a similarity between cultures in how the responsibility for learning now falls clearly on the shoulders of the individual.

While there was only a slight difference expected between Norway and U.S. on the individualism dimension, an even larger discrepancy was expected in the masculinity dimension. Here there was a predicted 54-point spread on Hofstede's 90-point system. But once again we found that leveling between the cultures has occurred. 
The ICT use from U.S. interviewees - highly masculine on Hofstede's dimension —and Norwegian interviewees - strongly feminine-looks very much alike. We find that in addition to their masculine characteristics such as assertiveness and workaholic tendencies, the U.S. also exhibits many feminine traits such as using ICTs to slow down the work pace of their lives. Norwegians, meanwhile, are talking about being competitive and carrying cell phones for work purposes all the time-very masculine traits. But Americans also talk about maintaining relationships with kids and friends - more feminine traits. So two themes are predominant in our MAS findings: a growing emphasis in Norway on using ICTs competitively and in the U.S. on using them for play and social support. So each of the two cultures has moved closer toward the style of the other, and thus their differences have been leveled.

We now turn to why this leveling has occurred between the United States and Norway, as displayed through ICT use. We propose two explanations for it. First, the leveling of national culture differences could simply be a function of the subculture we chose for this study - high-end ICT users. Perhaps those experienced with technology use it in similar ways, so the culture change we find is unique to this subculture. Support for this theory exists in our data, since one Norwegian interviewee claimed, "I have more in common with other high-end users than I do with inexperienced users in my own country." But even Hofstede's original work was situated inside a multi- national technology organization, IBM, and it is likely that those individuals were higher-end users of technology than the general population.

A second possible explanation and contributing factor is that leveling occurs through indirect and external events. For example, external events affect ICT use, and these new technology appropriations are indicators of a culture change. Our data categories of 9/11 (referring to the Sept. $11^{\text {th }}, 2001$ terrorist bombing of the U.S. World Trade Center) and the Dot.Com Crash (referring to the economic changes resulting from the U.S. stock-market crash of 2001) suggest that as a result of these losses, U.S. interviewees began to use technologies in more feminine ways. But while these events could have triggered a hard shift toward femininity, we also see evidence of slight shifts toward femininity in the first part of the U.S. data that was collected prior to these events. Norway has also had some triggering events that might account for leveling. It can be argued that the policy decision made by the Norwegian government to fund the country's ICT expansion increased ICT use and created a more masculine focus on the importance of competitiveness. Furthermore, during the last 15 years Norway has undergone massive privatization of government services as well as deregulation of industries such as telecommunication. To stay competitive and operate efficiently, all sectors have had to implement ICTs, and this no doubt created a more competitive, aggressive attitude, hence a more masculine focus. We found a number of Norwegian interviewee comments that made this connection to masculinity.

\section{Future Directions \& Limitations}

While we found few differences in Norwegian and U.S. culture that were due at least partly to ICT use, our study has limitations that we must acknowledge. First, while it placed no limits on the ICTs discussed in our interviews, we are also unable to directly compare the specific ICTs discussed. For example, we cannot "match" ICT use in that one interviewee from Norway might have used the cell phone extensively while one from the US continuously used a pager. It is our hope that by collecting such a large sample, we have minimized these differences, but they certainly still exist to some extent. Second, we used previously categorized data for this study. Despite our efforts to at least double code every step of the analysis, different categories might have emerged if the raw data had been originally categorized with this cultural comparison in mind.

While we make an argument earlier in the paper that supports the value of choosing US and Norway for comparison, this is also a limitation. First, the study contained interviewees from only these two countries. Since Hofstede originally found a fair amount of similarity between these national cultures, it wouldn't take much change in them for one to begin to see overlaps. Second, though we couched these 
findings in the context of high-end users, this subculture focus could itself be a limitation. Though it is nice to know more about this subculture, it makes generalizing to an entire population-even inside an organization-difficult.

Future studies might capture ideas from the above explanations and begin to test them. A multi-national study of high-end users might shed light on the characteristics of this subculture. It is important for these studies to focus on a micro approach, such as comparing a limited number of ICTs, in addition to a macro approach, such as this study. It would be particularly valuable to understand if organizations operating across cultures might use different ICTs yet use them in similar ways or to accomplish desirable objectives. Both theoretical and practical value can be surfaced if the leveling concept is further developed. It is also likely that an ICT like the Internet does not behave the same as a cell phone or a pager. Future studies might see if different ICTs (email vs. cellphone) contribute to the various Hofstede dimensions in different ways. The vast body of literature on group decision support systems might be an ideal place to examine these differences. Researchers have claimed and sometimes argued about how they either have embedded technical artifacts (Feenberg, 1994), or if those features designed into the technology are changed by interaction with users (Orlikowski, 2000). If Hofstede's framework were applied to this body of knowledge, additional insight would certainly result.

Finally, studies of notable triggering events can be undertaken to evaluate their impact-either direct or indirect - on ICT use and potentially national culture. This study was not consciously designed to collect data before and after September $11^{\text {th }}, 2001$; however we took advantage of the study opportunity and found some differences. Researchers can use our study as an impetus to explore serendipitous research timeframes. In addition, studies can be consciously designed to examine external triggering events. Perhaps major organizational changes can provide insight into this issue. Several existing theories such as diffusion of innovation (Rogers, 1983) and punctuated equilibrium (e.g. Tushmam \& Romanelli, 1985) might be a useful theoretical explanation for how use changes over time.

\section{Conclusion}

This study has combined social-psychological dispositions (Hofstede's cultural categories) with reports of individuals' use of technology (including how they use the computer, phone, and face-to-face communication) to show that culture- "how things are done here"-depends on individual skills, the presence of technology, and historical memory. Bringing this composite together means we can examine any single code from our data set and locate a cultural context for what an interviewee reported about their technology use. Our examination of these codes shows that the power of ICTs is that they cause cultures to do more things in similar ways. Furthermore, it is important for managers and scholars to develop a culturally based understanding of technology use in organizations and nations, as ICTs will continue to play a critical role in organizations across the globe.

This study of ICT use and national culture opens the door for others to critically examine similarities and differences in a variety of ICTs. The complexity of ICT use is not likely to decrease. Regularly we find that new ICTs emerge through technology advancement and by combining existing ICTs. As individuals make sense of ICTs, they will continue constructing, using, and modifying such technologies. As scholars, we have the task of studying usage patterns, adoption rates, effects, and impacts of new and existing ICT within and across national borders. It is through our theoretical contributions that we develop sustainable explanations for behavior. 


\section{References}

Aukrust, V., and Snow, C. (1998). Narratives and explanations during mealtime conversations in Norway and the U.S. Language and Society, 27, 221 - 246.

Avolio, B., Kahai, S., \& Dodge, G. (2000). E-leadership: Implications for theory, research, and practice. Leadership Quarterly, 11(4), 615-668.

Bauer, J. M., Berne, M, \& Maitland, C.F. (2002). Internet access in the European Union and in the United States. Telematics and Informatics, 19, 117-137.

Cagilitay, K. (1999). Culture and its effects on human-computer-interaction. Proceedings of Ed-Media 99, 1626-1634.

Calhoun, K. J., Teng J.T. C., Cheon, M. J. (2002). Impact of national culture on information technology usage behaviour: an exploratory study of decision making in Korea and the USA. Behavior \& Information Technology, 21 (4), 293-302.

Caron, A. H., Giroux, L., and Douzou, S. (1989). Uses and impacts of home computers in Canada: A process of reappropriation, in J. L. Salvaggio and J. Bryant (eds.), Media Use in the Information Age: Emerging Patterns of Adoption and Consumer Use (pp. 147-162). Erlbaum, Hillsdale, NJ.

Charmaz, K. (2000). Grounded theory: objectivist and constructivist methods, In N. K. Denzin and Y. S. Lincoln (Eds.), Handbook of Qualitative Research. (2 ${ }^{\text {nd }}$ Ed.), (pp. 509-535), Thousand Oaks, CA: Sage Publications.

Cronin, M. J. (1996). Global advantage on the Internet: From corporate connectivity to international competitiveness, Van Nostrand Reinhold, New York

Dafoulas, G., \& Macaulay, L. (2001). Investigating cultural differences in software teams. Electronic Journal on Information Systems in Developing Countries, 7(4), 1-14.

Daft, R. L., \& Lengel, R. H. (1986). Organizational information requirements, media richness and structural design. Management Science, 32(5), 554-571.

Dewett, T. \& Jones, G. R. (2001). The role of information technology in the organization: A review, model, and assessment. Journal of Management, 27 (3), 313-346.

Drucker, P. F. (1993). Post-capitalist society. New York, Harper Business.

El-Shinnawy, M., \& Markus, L. M. (1997). The poverty of media richness theory: Explaining people's preferences for electronic mail and voice mail. International Journal of Human Computer Studies, 46, 443-467.

El-Shinnawy, M., \& Vinze, A. S. (1997). Technology, culture and persuasiveness: A study of choice-shifts in group settings. International Journal of Human-Computer Studies, 47, 473-496.

Feenberg, Andrew (1999). Questioning technology. London and New York: Routledge.

Fernandez, D., Carlson, D., Stepina, L., \& Nicholson, J. (1997). Hofstede's country classification 25 years later. The Journal of Social Psychology, 137 (1), 43-54.

Ferraro, G.P. (1994). The cultural dimensions of international business, $2^{\text {nd }}$ ed. NJ, 1994

Flanagin, A.J., \& M.J. Metzger (2001). Internet use in the contemporary media environment. Human Communication Research, 27, 153-181.

Fulk, J., \& Boyd, B. (1991). Emerging theories of communication in organizations. Journal of Management, 17, 407-446.

Gannon, M. J. and Associates (1997). Understanding global cultures: Metaphorical journeys through 17 countries. Sage Publication, CA, 1994.

Garton, L., \& Wellman, B. (1995). Social impacts of electronic mail in organizations: A review of the research literature. In B.R. Burleson (Ed.), Communication Yearbook 18, (pp. 434-453), Thousand Oaks, CA: Sage.

Gattiker, U.E., Nelligan, T.W. (1988). Computerized offices in Canada and the United States: Investigating dispositional similarities and differences. Journal of Organizational Behavior, 9, 77-96.

Glaser, B. \& A. Strauss (1967). The discovery of grounded theory. Chicago, IL: Aldine.

Glaser, B. (1978). Theoretical sensitivity. Mill Valley, CA: The Sociology Press.

Goodman, S. E., Press, L. I., Ruth, S. R., \& Rutkowski, A. M. (1994). The global diffusion of the Internet: Patterns and problems. Communications of the ACM, 37(8), 27-31. 
Leveling Differences and Reinforcing Similarities

Gudykunst, W. B., \& Ting-Toomey, S. (1988). Culture and affective communication. American Behavioral Scientist, 31, 384-400.

Hall, E. T. (1976). Beyond culture, Anchor Press, NY.

Hamelink, C.J. (1999). Language and the right to communicate. Media Development, Vol. XLVI, 4/1999, London, WACC.

Henten, A., \& Kristensen, T. M. (2000). Information society visions in the Nordic countries. Telematics and informatics, 17, $77-103$

Herbig, P. A. (1994). The Innovation matrix: Culture and structure prerequisites to innovation. Westport, CT: Quorum Books.

Hiltz, S. R., Turoff, M. (1978). The network nation. Reading, MA: Addison-Wesley.

Ho, T.H., Raman, K.S., \& Watson, R.T. (1999). Group decision support systems: The cultural factor. Proceedings of the Tenth Annual International Conference on Information Systems, Boston, 119-129.

Hofstede, G. (1980). Culture's consequences: International differences in work related values. Newbury Park, CA: Sage.

Hofstede, G. (1983). Dimensions of national cultures in fifty countries and three regions. In J. B. Deregowski, S. Dziurawiec, \& R. C. Annis (Eds.), Expiscations in cross-cultural psychology. Lisse, Netherlands: Swets \& Zeitlanger.

Hofstede, G. (1991). Culture and organizations: Software of the mind. London, UK: McGraw Hill.

Hofstede, G (2001). Culture's recent consequences: Using dimension scores in theory and research. International Journal of cross cultural management, 1(1), 11-30.

Hofstede, G. J., (2000). The information age across culture. Proceedings of 5th AIM conference - Information Systems and Organizational Change. CD-Rom, 10pp.

Hollingshead, A. B., \& Contractor, N. S. (2002). New media and organizing at the group level. In S. Livingstone \& L. Lievrouw (Eds.), Handbook of New Media (pp. 221-235). London: Sage.

Jarvenpaa, S., Rao, V. S., \& Huber, G. P. (1988). Computer support for meetings of groups working on unstructured problems: A field experiment. MIS Quarterly (December), 645-666.

Kluckhohn, F. \& Strodtbeck, F.L. (1961) variations in value orientations. Peterson, IL.

Kroeber, A. L., \& Kluckhohn, C. (1952). Culture: a critical review of concepts and definitions. Papers of the Peabody Museum of American Archaeology and Ethnology, 47. Cambridge, MA: Harvard University.

Latane, B., \& Bourgeois, M. J. (1996). Experimental evidence for dynamic social impact: The emergence of subcultures in electronic groups. Journal of Communication, 46(4), 35-47.

Leidner D. E., Carlsson S., Elam J. \& Corrales, M. (1999). Mexican and Swedish managers' perceptions of the impact of EIS on organizational intelligence, decision making, and structure. Decision Sciences, 30 (3), 633-658.

Lincoln Y.S \& Guba E.B. (1985). Naturalistic Enquiry. London: Sage

Livingstone, S. \& Lievrouw, L. (2002). Handbook of new media. London: Sage.

Lundby, K. (2002). The networked Nordic region: Connections and community. ICA News, September, 8-9.

McGrath, J. E., \& Hollingshead, A. B. (1993). Putting the "group" back in group support systems: Some theoretical issues about dynamic processes in groups with technological enhancements. In L. M. Jessup \& J. S. Valacich (Eds.), Group Support Systems (pp. 78-96). NY: Macmillan.

Maitland, C. (1999). Global diffusion of interactive networks. The Impact of Culture AI \& Society, 13, 341-35.

Maitland, C. \& Bauer, J. (2001). National level culture and global diffusion: The case of the Internet. In Charles Ess (Ed.), Culture, Technology, Communication: Towards an Intercultural Global Village. (pp. 87-128), Albany, NY: State Un iversity of New York Press.

Merchant, J. E. (2002). Communicating across borders: A proposed model for understanding cross-cultural issues for the successful strategic implementation of information systems. Proceedings of InSITE, 1031-1040.

Mejias, R. J., Shepherd, M. M., Vogel, D. R., \& Lazaneo, L. (1996/97). Consensus and satisfaction levels: A cross-cultural comparison of GSS and non-GSS outcomes within and between the United States and Mexico. Journal of Management Information Systems, 13(3), 1996-97, pp. 137-161. 
Miles, M. B., \& Huberman, A. M. (1994). Qualitative data analysis: An expanded sourcebook (2nd ed.). Thousand Oaks, CA: Sage.

Mooij, M. (2000). The future is predictable for international marketers: Converging incomes lead to diverging consumer behavior. International Marketing Review, 17(2), 103-113.

Morse, J.M. (1991). Strategies for sampling. In Morse J.M. (Ed.). Qualitative Nursing Research: A Contemporary Dialogue, (pp. 126-145). London: Sage.

National Information Task Force (1993). The national information infrastructure - Agenda for action. Washington, DC.

Orlikowski, W.J. \& Robey, D. (1991). Information technology and the structuring of organizations. Information Systems Research, 2(2), 143-169.

Orlikowski, W.J. (2000). Using technology and constituting structures: A practice lens for studying technology in organizations. Organization Science, 11, 404-428.

Patton, M. Q., (1990). Qualitative evaluations and research methods ( ${ }^{\text {nd }}$ ed.). London: Sage.

Poole, M. S., \& DeSanctis, G. (1990). Understanding the use of group decision support systems: The theory of adaptive structuration. In J. Fulk and C. Steinfield (Eds.), Organizations and Communication Technology, (pp. 173-193), Newbury Park, CA: Sage.

Png, I.P.L., Tan, B.C.Y. \& Wee, K.L. (2001). Dimensions of national culture and corporate adoption of IT infrastructure. IEEE Transactions on Engineering Management, 48 (1), 36-45.

Rathod, M. M., \& Miranda, S.M. (1999). Teleworking and psychological distance: The mediating effects of culture and technology in four countries. Proceedings of ACM SIGCPR, New Orleans, USA.

Rice, R. E., D'Ambra, J. \& More, E. (1998). Cross-cultural comparison of organizational media evaluation and choice. Journal of Communication, 48, 3-26.

Rogers, E. M. (1983). Diffusion of innovations. (3rd ed.). New York: The Free Press.

Ronen, S., \& Shenkar, O. (1985). Clustering countries on attitudinal dimensions: A review and synthesis. Academy of Management Review, 10(3), 435-454.

Sackman, S. (1997). Cultural complexity in organizations: Inherent contrasts and contradictions. Sage.

Samferdselsdepartementet: 'Den norske IT-veien - bit for bit' (The Norwegian IT-way - bit by bit). Available on the Web at http://odin.dep.no/html/nofovalt/offpub/utrednin/it/it-veien

Samovar, L.A., Porter, R.E., \& Jain, N.C. (1981). Understanding intercultural communication. Belmont, CA: Wadsworth.

Savolainen, R. (1999). The role of the Internet in information seeking: Putting the networked services in context. Information Processing and Management, 35, 765-782.

Sitkin, S.B., Sutcliff, K. M. \& Barrios-Choplin, J. R., (1992). A dual-capacity model of communication media choice in organizations. Human Communication Research, 18, 563-598.

Slack, D. S., \& Wise, M. J. (2002). Cultural Studies and Technology. In S. Livingstone \& L. Lievrouw (Eds.), Handbook of New Media (pp. 221-235). London: Sage. Available on the Web at http://www.spcomm.uiuc.edu/users/nosh/manuscripts/hollingshead contractor 2002.pdf

Smith, P. B. (2002). Culture's consequences: Something old and something new. Human Relations, 55(1), 119-137.

Smith, P. B. (2001). The end of the beginning? International Journal of Cross Cultural Management, 1(1), 21-24.

Sondergaard, M. 1990. Hofstede's consequences: a study of reviews, citations and replications. Organization Studies. 15(3), 447-456.

Sondergaard, M. (1994). Hofstede's consequences: A study of reviews, citations and replications. Organisation Studies, 15(3), 447-456.

Spradley, J. P. (1979). The ethnographic interview. New York: Holt Reinhart \& Winston.

Sproull, L. \& Kiesler, S. (1986). Reducing social context cues: Electronic mail in organizational communication. Management Science, 32, 1492-1512.

Sproull, L., \& Kiesler, S. (1991). Connections: New ways of working in the networked organization. Cambridge: The MIT Press. 
Leveling Differences and Reinforcing Similarities

Stephens, K., Browning, L., Soernes, J-O., Schmisseur, A. M., \& Saetre, A. S. (2002). A reflexive model of ICT practices in Norway and the US: An integration of adaptive structuration theory and self-organizing systems theory. Paper presented at the International Communication Association's Annual Conference, Seoul, Korea

Stohl, C. (2001). Globalizing organizational communication. In F. Jablin \& L. Putnam (Eds.), The New Handbook of Organizational Communication (pp. 323-375). Thousand Oaks, CA: Sage.

Straub, D. W. (1994). The effect of culture on IT diffusion: e-mail and fax in Japan and the US. Information Systems Research, 5(1), 23-47.

Straub, D. W. \& Karahanna, R. (1998). Knowledge worker communications and recipient availability: Toward a task closure explanation of media choice. Organization Science, 9(2), 160-175.

Straub, D. W, Loch, K., Evaristo, R., Karahanna, E. \& Strite, M. (2002). Toward a theory-based measurement of culture. Journal of Global Information Management. 10(1), 13-23.

Straub, D. W., Keil, P., \& Brenner, A. (1997). Testing the technology acceptance model across cultures: A three country study. Information \& Management, 31(1), 1-11.

Strauss, A., \& Corbin, J. (1990). Basics of qualitative research: Grounded theory procedures and techniques. Newbury Park, CA: Sage.

Strauss, A. (1970). Discovering new theory from previous theory. In T. Shibutani (Ed.), Human Nature and Collective Theory. Englewood Cliffs, NJ: Prentice-Hall Publishing.

Tan, B.C.Y., Wei, K.K., Watson, R.T., Clapper, D.L. \& McLean, E.R. (1998). Computer-mediated communication and majority influence: Assessing the impact in an individualistic and a collectivistic culture. Management Science, 44(9), 12631278.

Tayeb, M. (2001). Conducting research across cultures: Overcoming drawbacks and obstacles. International Journal of Cross Cultural Management, 1(1), 91-108.

Trevino, L.K., Daft, R.L. \& Lengel, R.H. (1990). Understanding managers' media choices: A symbolic interactionist perspective. In J. Fulk and C. Steinfield's (Eds.) Organizations and Communication Technology, (pp. 71-94), Newbury Park, CA: Sage.

Triandis, H. C. (1995). Individualism and collectivism. Boulder, CO: Westview.

Trompenaars, F., (1993). Riding the waves of culture: Understanding diversity in global business. London: The Economist Books.

Tushman, M., \& Romanelli, E. (1985). Organizational evolution: A metamorphosis model of convergence and reorientation. In L.L. Cummings and B.M. Staw (Eds.), Research in Organizational Behavior (pp. 171-222), 7, Greenwich, CT: JAI Press.

Ulijn, J., Lincke, A., \& Karakaya, Y. (2001). Non-face-to-face international business negotiation: How is national culture reflected in this discourse? IEEE Transactions on Professional Communication, 44. 126-137.

Van Birgelen, M, Ruyter, K.D, Jong, A.D., \& Wtzels, M. (2002). Customer evaluations of after-sale service contact modes: An empirical analysis of national culture's consequences. International Journal of Research in Marketing, $19,43-64$.

Veiga, J.F., S. Floyd \& Dechant, K. (2001). Towards modelling the effects of national culture on IT implementation and acceptance. Journal of Information Technology, 16, (3)3, 145-158.

Vogel, D., Davison, R.M, Shroff, R.H., \& Qureshi, S. (2001). Sociocultural learning in globally distributed teams: An exploratory study. Proceedings of Informing Science Conference. Krakow, Poland, 2001, pp. 527-536.

Zack, M. H., \& McKenney, J. L. (1995). Social context and interaction in ongoing computer-supported management groups. Organization Science, 6(4), 394-422.

\section{Biographies}

Jan-Oddvar Sørnes is a Research Fellow/lecturer at Bodø Graduate School of Business at Bodø University, Norway, and a Doctoral student in the Department of Industrial Economics and Technology Management at the Norwegian University of Science and Technology in Trondheim, Norway. Jan's research focus is on ICT use in organizations and e-learning. He has 10 years of experience with elearning and ICT use in higher education. Jan teaches introductory courses in Computer Science and In- 
formation Systems. He has a Masters degree from Michigan State University, and an undergraduate degree from University of Idaho.

Keri Stephens is a doctoral student in organizational communication in the Department of Communication Studies at the University of Texas at Austin. Keri's focus is on the use of research knowledge for applied problems and has written award winning papers on the use of information/communication technologies and completes research on a variety of organizational communication and technology issues including virtual immediacy, crisis communication, representation and identity, and collaborative innovation. She has a Masters degree from the University of Texas at Austin and graduated with an undergraduate degree from Texas A\&M University.

Alf Steinar Sætre is an Associate Professor in the Department of Industrial Economics and Technology Management at the Norwegian University of Science and Technology in Trondheim, Norway. Alf

Steinar's research focuses in innovation and ICT use in organizations, new venture financing and orga nizational communication. Alf Steinar's Ph. D is from The University of Texas at Austin; his MSc is from The Norwegian School of Economics and Business Administration.

Larry Davis Browning is a Professor of Organizational Communication and Director of Graduate Studies in the Department of Communication Studies at the University of Texas at Austin. Larry's consulting work focuses on narrative communication, the use of information technologies to communicate, the use of teams to complete projects, strategic planning, and work improvement methods. Larry's research on organizations is published in a variety of communication and management journals including: Communication Monographs, Academy of Management Journal, Communication Theory, Journal of Management, Communication Studies, Communication Education, Journal of Organizational Change Management, Journal of Applied Communication Research, Electronic Journal of Communication, Handbook of Organizational Communication, and Communication Yearbook 13. His recent scholarship, published in 2000, (with Judy Shetler) is: Sematech: Saving the U.S. Semiconductor Industry. College Station, TX: Texas A \& M University Press. Larry's Ph. D is from Ohio State; his MA and BS are from Oklahoma University. 